\title{
Artikler om systematisk teologi og bibelvidenskaberne
}

Carsten Pallesens artikel om 'homoousia' indleder dette nummer af Dansk Teologisk Tidsskrift. Begrebet, der kan udledes fra bekendelsen

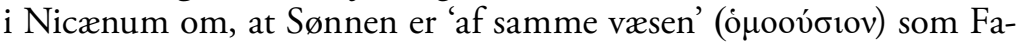
deren, søges fortolket gennem hermeneutiske og mediefilosofiske indsigter om sprog og krop, og dets betydning for treenighedslæren hos Luther og posthegelianske filosoffer diskuteres i denne sammenhæng. Jeppe Bach Nikolajsen søger at vise, at medens den lutherske teologiske tradition i Danmark traditionelt betoner den teologiske etiks almene bestemmelse, har de vestlige samfund efterhånden udviklet sig i en pluralistisk retning, der gør det mere nærliggende at udvikle en teologisk etik, der i højere grad udtrykker dens partikularitet og specielle karakter. Til dette empiriske argument føjer Nikolajsen yderligere teologiske argumenter. Afsluttende søger han at vise, hvordan hans position vil kunne bidrage til en fælles etisk samtale i det pluralistiske samfund.

Rikke Hvarregaard Andersen beskæftiger sig med myten om de faldne engle, der på baggrund af 1 Mos 6,2.4 blev udviklet i den antikke jødiske 'Vægternes Bog', der indgår som kap. 1-36 i Første Enoksbog. Det er blevet hævdet, at denne myte påvirkede Jubilæerbogen og de to Qumrantekster Sekthåndbogen og Damasusskriftet. Andersens undersøgelse bekræfter på den ene side, at der er sådanne påvirkninger, men argumenterer på den anden side for, at det er en stærkt begrænset indflydelse, idet de senere tekster fremhæver andre pointer vedrørende syndens og det ondes oprindelse eller karakter, end der var tale om i Vægternes Bog.

Den afsluttende artikel rummer første del af et længere arbejde ved Mogens Müller om Septuagintas betydning for udfoldelsen af nytestamentlig teologi. Den græske oversættelse af Det Gamle Testamente betød, at der for de nytestamentlige forfattere allerede eksisterede et teologisk græsk vokabular, som de kunne benytte. Müller opridser en forskningsdiskussion, der har kredset om, hvorvidt Septuaginta mere negativt betyder, at de gammeltestamentlige teksters betydningsfylde er blevet indskrænket, eller om oversættelsen mere positivt var en berigelse af Det Nye Testamente og en adækvat fortolkning af det hebraiske forlæg. Müller vil dog gerne ud over dikotomien mellem jødedom og hellenisme og i stedet se Septuaginta som en afspejling af den daværende jødedoms fortolkningsunivers overhovedet. 